\title{
Imprensa e liberdade de expressão
}

Supremo Tribunal Federal (STF)

\section{ARGUIÇÃO DE DESCUMPRIMENTO DE PRECEITO FUNDAMENTAL 130-7 DISTRITO FEDERAL}

\section{Voto}

\section{O SENHOR MINISTRO CARLOS AYRES BRITTO (Relator)}

Uma vez assentada a adequação da presente arguição de descumprimento de preceito fundamental (ADPF) como ferramenta processual de abertura da jurisdição deste Supremo Tribunal Federal, e não havendo nenhuma outra questão preliminar a solver, passo ao voto que me cabe proferir quanto ao mérito da questão. Fazendo-o, começo por me impor a tarefa que certamente passa pela curiosidade inicial de cada um dos senhores ministros: saber até que ponto a proteção constitucional brasileira à liberdade de imprensa corre parelha com a relevância intrínseca do tema em todos os países de democracia consolidada. A começar pelos Estados Unidos da América, em cuja Constituição, e por efeito da primeira emenda por ela recebida, está fixada a regra de que "O Congresso não legislará no sentido de estabelecer uma religião, ou proibindo o livre exercício dos cultos; ou cerceando a liberdade de palavra, ou de imprensa (...)" (art. I). 
15. Em palavras diferentes, o que certamente passa pelo intelecto de cada qual dos meus Pares é saber se o regime constitucional da imprensa, em nosso País, guarda conformidade com o fundamental e insubstituível papel que ela desempenha enquanto plexo de "atividades" e também como o somatório dos órgãos ou "meios de comunicação social". Plexo de atividades e somatório dos órgãos ou meios de comunicação social, porque assim é como dispõe o $\S 5^{\circ}$ do art. 220 , combinadamente com os $\S \S 1^{\circ}$, $2^{ }$e $3^{\circ}$ do art. 222 da Constituição de 1988.

16. Deveras, todo exame normativo-constitucional que, entre nós, tenha na liberdade de imprensa o seu específico ponto de incidência, há de começar pela constatação de que, objetivamente, a imprensa é uma atividade. Uma diferenciada forma do agir e do fazer humano. Uma bem caracterizada esfera de movimentação ou do protagonismo dessa espécie animal que Protágoras (485/410 a.C) tinha como "a medida de todas as coisas". Mas atividade que, pela sua força de multiplicar condutas e plasmar caracteres, ganha a dimensão de instituição-ideia. Locomotiva sociocultural ou ideia-força. Nessa medida, atividade (a de imprensa) que se põe como a mais rematada expressão do jornalismo; quer o jornalismo como profissão, quer o jornalismo enquanto vocação ou pendor individual (pendor que é frequentemente identificado como arte, ou literatura). Donde a Constituição mesma falar de "liberdade de informação jornalística" (§ 1ํo do art. 220), expressão exatamente igual a liberdade de imprensa.

17. Já do ângulo subjetivo ou orgânico, a comprovação cognitiva é esta: a imprensa constitui-se num conjunto de órgãos, veículos, "empresas", "meios", enfim, juridicamente personalizados (§ 5o do art. 220, mais o $\S 5$ o do art. 222 da Constituição Federal). Logo, subjetivamente considerada, a imprensa é instituição-entidade, instituição-aparelho, instituição-aparato. Mas seja a imprensa como objetivo sistema de atividades, seja como subjetivados aparelhos, a comunicação social é mesmo o seu traço diferenciador ou signo distintivo. As duas coisas sempre englobadas (instituição-ideia e instituiçãoentidade), pois o fato é que assim binariamente composta é que a imprensa consubstancia um tipo de comunicação que não desborda do significado que se contém nos dicionários da língua portuguesa; ou seja, comunicação é ato de comunicar, transmitir, repassar, divulgar, revelar. No caso da imprensa, comunicar, transmitir, repassar, divulgar, revelar: a) informações ou notícias de coisas acontecidas no mundo do ser, que é o mundo das ocorrências táticas; b) o pensamento, a pesquisa, a criação e a percepção humana em geral, estes situados nos escaninhos do nosso cérebro, identificado como a sede de toda inteligência e de todo sentimento da espécie animal a que pertencemos. 
18. Sequencio imediatamente o raciocínio: a modalidade de comunicação que a imprensa exprime não se dirige a essa ou aquela determinada pessoa, nem mesmo a esse ou aquele particularizado grupo, mas ao público em geral. Ao maior número possível de pessoas humanas. Com o que a imprensa passa a se revestir da característica central de instância de comunicação de massa, de sorte a poder influenciar cada pessoa de per se e até mesmo formar o que se convencionou chamar de opinião pública. Opinião pública ou modo coletivo de pensar e sentir acerca de fatos, circunstâncias, episódios, causas, temas, relações que a dinamicidade da vida faz emergir como respeitantes à coletividade mesma. Incumbindo à imprensa o direito e ao mesmo tempo o dever de sempre se postar como o olhar mais atento ou o foco mais aceso sobre o dia a dia do Estado e da sociedade civil. O que enseja a tomada de posições, a feitura de escolhas e a assunção de condutas igualmente massivas, que são direitos elementares de todo grupamento humano o agir e o reagir como conjunto mesmo. Donde a imprensa, matriz por excelência da opinião pública, rivalizar com o próprio Estado nesse tipo de interação de máxima abrangência pessoal.

19. Foi precisamente em função desse bem mais abrangente círculo de interação humana que o nosso Magno Texto reservou para a imprensa todo um bloco normativo com o apropriado nome "Da Comunicação Social" (capítulo V do título VIII). Capítulo de que emerge a Imprensa como de fato ela é: o mais acessado e por isso mesmo o mais influente repositório de notícias do cotidiano, concomitantemente com a veiculação de editoriais, artigos assinados, entrevistas, reportagens, documentários, atividades de entretenimento em geral (por modo especial as esportivas e musicais, além dos filmes de televisão), pesquisas de opinião pública, investigações e denúncias, acompanhamento dos atos do Poder e da economia do País, ensaios e comentários críticos sobre arte, religião e tudo o mais que venha a se traduzir em valores, interesses, aspirações, expectativas, curiosidades e até mesmo entretenimento do corpo societário. Pelo que encerra a mais constante e desembaraçada comunicação de ideias, ensaios, opiniões, testemunhos, projeções e percepções de toda ordem, passando mais e mais a ver a si mesma e a ser vista pela coletividade como ferramenta institucional que transita da informação em geral e análise da matéria informada para a investigação, a denúncia e a cobrança de medidas corretivas sobre toda conduta que lhe parecer (a ela, imprensa) fora do esquadro jurídico e dos padrões minimamente aceitáveis como próprios da experiência humana em determinada quadra histórica. Não sendo exagerado afirmar que esse estádio multifuncional da imprensa é, 
em si mesmo, um patrimônio imaterial que corresponde ao mais eloquente atestado de evolução político-cultural de todo um povo. Status de civilização avançada, por conseguinte.

20. É certo que a nossa Constituição Federal somente faz expresso uso do substantivo "imprensa" numa solitária passagem, e ainda assim como sinônimo de mídia impressa ou escrita. "Veículo de comunicação em papel ou impresso" (Walter Ceneviva). Isso por oposição à mídia eletrônica, abarcante da radiodifusora e televisiva, consoante a seguinte transcrição:

Art. 139. Na vigência do estado de sítio decretado com fundamento no art. 177, I, só poderão ser tomadas contra as pessoas as seguintes medidas:

$\mathrm{I}-\ldots$

III - restrições relativas à inviolabilidade da correspondência, ao sigilo das comunicações, à prestação de informações e à liberdade de imprensa, radiodifusão e televisão, na forma da lei.

21. Não menos certo, porém, que essa diferenciação entre mídia impressa e mídia radiodifusora e televisiva (eletrônica, dissemos) atende à consideração de que somente as duas últimas é que são constitucionalmente tipificadas como serviços públicos, próprios da União Federal. Serviços públicos sempre titularizados pela União, frise-se, porém complementarmente prestados pela iniciativa privada, mediante contratos de concessão, ou permissão, tanto quanto por ato unilateral e precário de autorização. É como está na alínea $a$ do inciso XI do art. 21 da nossa Lei Fundamental, em combinação com a cabeça do art. 223 da mesma Carta Magna, a saber:

Art. 21. Compete à União: XI - explorar, diretamente ou mediante autorização, concessão ou permissão: a) os serviços de radiodifusão sonora e de sons e imagens.

Art. 223. Compete ao Poder Executivo outorgar e renovar concessão, permissão e autorização para o serviço de radiodifusão sonora e de sons e imagens, observado o princípio da complementaridade dos sistemas privado, público e estatal.

22. Já a mídia impressa, além de se constituir em sistema de atividades e conjunto de empresas tipicamente privadas, "independe de licença da 
autoridade" quanto à sua "publicação" ( $\$ 52$ do artigo constitucional de

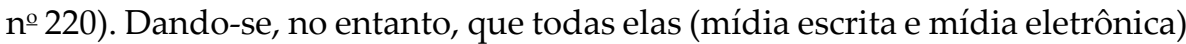
passam a compor "as atividades" e "Os meios de comunicação social" ainda há pouco referidos como objeto de normação do $\S 5$ o do art. 220 da CF, mais os $\S \S 1^{\circ}$, 2으, 3o e 5o do art. 222. Meios de comunicação social ou simplesmente "empresas jornalísticas e de radiodifusão sonora e de sons e imagens", segundo a linguagem do $\S 1^{\circ}$ do art. 222 da mesma Lei Fundamental brasileira.

23. Numa frase, estamos a lidar com atividades e meios ou empresas de comunicação social que, no seu conjunto, encerram o estratégico setor da imprensa livre em nosso País. Ficando de fora do conceito de imprensa, contudo, por absoluta falta de previsão constitucional, a chamada "Rede Mundial de Computadores - INTERNET". Artefato ou empreitada tecnológica de grandes e sedutoras possibilidades informativas e de relações interpessoais, sem dúvida, dentre elas a interação em tempo real dos seus usuários; ou seja, emissores e destinatários da comunicação internetizada a dispor da possibilidade de inverter as suas posições a todo instante. $\mathrm{O}$ fisicamente presencial a cada vez mais cede espaço ao telepresencial (viagem que vai do concreto ao virtual), porém, ainda assim, constitutivo de relações sem a menor referência constitucional. O que se explica em função da data de promulgação da Carta Política brasileira (5 de outubro de 1988), quando os computadores ainda não operavam sob o tão refinado quanto espantoso sistema eletrônicodigital de intercomunicação que veio, com o tempo, a se chamar de "rede".

24. Pois bem, assim binariamente concebida e praticada entre nós é que a imprensa possibilita, por modo crítico incomparável, a revelação e o controle de praticamente todas as coisas respeitantes à vida do Estado e da sociedade. Coisas que, por força dessa invencível parceria com o tempo, a ciência e a tecnologia, se projetam em patamar verdadeiramente global. Com o mérito adicional de se constituir, ela, imprensa, num necessário contraponto à leitura oficial dos fatos e suas circunstâncias, eventos, condutas e tudo o mais que lhes sirva de real motivação. Quero dizer: a imprensa como alternativa à explicação ou versão estatal de tudo que possa repercutir no seio da sociedade, conforme realçado pelo jurista, deputado federal e jornalista Miro Teixeira, um dos subscritores da presente ADPF. O que já significa visualizar a imprensa como garantido espaço de irrupção do pensamento crítico em qualquer situação ou contingência. Pensamento crítico ou racionalmente exposto, com toda sua potencialidade emancipatória de mentes e espíritos. Não aquele pensamento sectariamente urdido, ou então superficialmente engendrado, quando não maquinadamente elaborado para distorcer fatos 
e biografias. Sendo de toda relevância anotar que, a título de reforço à mantença dessa verdadeira relação de inerência entre o pensamento crítico e a imprensa livre, a própria Constituição impõe aos órgãos e empresas de comunicação social a seguinte interdição: “Os meios de comunicação social não podem, direta ou indiretamente, ser objeto de monopólio ou oligopólio" (§ 5o do art. 220). Norma constitucional de concretização de um pluralismo finalmente compreendido como fundamento das sociedades autenticamente democráticas; isto é, o pluralismo como a virtude democrática da respeitosa convivência dos contrários (o necessário consenso é apenas quanto às regras do jogo, conforme enuncia Norberto Bobbio em seu clássico livro "O futuro da democracia" ${ }^{1}$ ). Pluralismo, enfim, que a nossa Constituição prestigia em duas explícitas oportunidades: no seu preâmbulo e no inciso V do art. 1º pluralismo político; ali, pluralismo cultural ou social genérico.

25. Sem maior esforço mental, portanto, vê-se que a imprensa passou a desfrutar de tamanha importância na vida contemporânea que já faz da sua natureza de focada instância de comunicação social o próprio nome da sociedade civil globalizada: sociedade de informação, também chamada de sociedade de comunicação. Preservada a amplitude massiva dos seus destinatários ou público-alvo e sempre na perspectiva da encarnação de um direito-dever inarredável: o da instância por excelência do pensamento crítico ou emancipatório. Ele próprio, pensamento crítico ou libertador, a pedagogicamente introjetar no público em geral todo apreço pelo valor da verdade como categoria objetivamente demonstrável, o que termina por forçar a imprensa mesma a informar em plenitude e com o máximo de fidedignidade.

26. Convém insistir na afirmativa: por efeito dessa relação de mútua e benfazeja influência entre a imprensa e seus massivos destinatários, o caminho consequente ou como que natural a seguir só pode ser o da responsabilidade de jornalistas e órgãos de comunicação social. Responsabilidade que torna intrinsecamente meritórios uns e outros. Tudo a possibilitar a formação de uma confortável clientela ou corpo de destinatários, que vai eficazmente contrabatendo, com a incessante subida dos seus padrões de seletividade, o personalístico peso dos agentes públicos e dos empresários do ramo, ou mesmo desse ou daquele jornalista em apartado. Seletividade, de sua parte, que opera como antídoto social que o tempo não cessa de aprimorar contra

1 Doutrina Bobbio: “Democracia é definida como um conjunto de regras de procedimento para a formação de decisões coletivas em que está prevista e facilitada a participação mais ampla possível dos interessados". 
os abusos e desvios da imprensa dita burguesa; quer dizer, resquício de um modelo de imprensa que investe no atraso mental das massas e ainda se disponibiliza para o servilismo governamental, quando não para o insidioso desprestígio das instituições democráticas e o dogmatismo tão confessional quanto mercantil. Argentário. Também assim, antídoto contra os desvarios sensacionalistas, o açodamento do "furo de reportagem" (o escritor e jurista Manuel Alceu Affonso Ferreira bem o diz), a superficialidade e até mesmo a chantagem, que ninguém é ingênuo ou alienado ao ponto de não admitir que profissionais e órgãos de imprensa ainda estão sujeitos, sim, àquelas vicissitudes que Rui Barbosa tão bem denunciou com estas palavras, na conhecida monografia "A Imprensa e o Dever da Verdade" (prefaciada, justamente, e com pena de mestre, pelo citado jurista Manuel Alceu Affonso Ferreira):

Em quatro palavras se poderá encartar uma calúnia. Mas pode ser que a demonstração da falsidade não caiba toda num discurso. Uma só proposição dará, talvez, para se verter no espírito humano um erro tremendo. Mas uma vez lançado ao mundo, sabe Deus que de contestações, raciocínios e debates se não cansariam, porventura, ainda assim, debalde, em lhe dar combate (p. 27, Editora Papagaio, ano de 2004).

27. Mas a decisiva questão é comprovar que o nosso Magno Texto Federal levou o tema da liberdade de imprensa na devida conta. Deu a ela, imprensa, roupagem formal na medida exata da respectiva substância. Pois é definitiva lição da História que, em matéria de imprensa, não há espaço para o meiotermo ou a contemporização. Ou ela é inteiramente livre, ou dela já não se pode cogitar senão como jogo de aparência jurídica. É a trajetória humana, é a vida, são os fatos, o pensamento e as obras dos mais acreditados formadores de opinião que retratam sob todas as cores, luzes e contornos que imprensa apenas meio livre é um tão arremedo de imprensa como a própria meia verdade das coisas o é para a explicação cabal dos fenômenos, seres, condutas, ideias. Sobretudo ideias, cuja livre circulação no mundo é tão necessária quanto o desembaraçado fluir do sangue pelas nossas veias e o desobstruído percurso do ar pelos nossos pulmões e vias aéreas. O que tem levado interlocutores sociais de peso - diga-se de passagem - a se posicionar contra a exigência de diploma de nível superior para quem se disponha a escrever e falar com habitualidade pelos órgãos de imprensa.

28. Se é assim, não há opção diferente daquela que seguramente fez o nosso Magno Texto Republicano: consagrar a plenitude de uma liberdade 
tão intrinsecamente luminosa que sempre compensa, de muito, de sobejo, inumeravelmente, as quedas de voltagem que lhe infligem profissionais e organizações aferrados a práticas de um tempo que estrebucha, porque já deu o que tinha de dar de voluntarismo, chantagem, birra, perseguição. Esparsas nuvens escuras a se esgueirar, intrusas, por um céu que somente se compraz em hospedar o sol a pino. Exceção feita, já o vimos, a eventuais períodos de estado de sítio, mas ainda assim "na forma da lei". Não a vontade caprichosa ou arbitrária dos órgãos e autoridades situados na cúpula do Poder Executivo, ou mesmo do Poder Judiciário.

29. O que se tem como expressão da realidade, portanto, é, de uma banda, um corpo social progressivamente esclarecido por uma imprensa livre e, ela mesma, plural (visto que são proibidas a oligopolização e a monopolização do setor). Corpo social também progressivamente robustecido nos seus padrões de exigência enquanto destinatário e consequentemente parte das relações de imprensa. De outra banda, uma imprensa que faz de sua liberdade de atuação um necessário compromisso com a responsabilidade quanto à completude e fidedignidade das informações comunicadas ao público. Do que decorre a permanente conciliação entre liberdade e responsabilidade, até porque, sob o prisma do conjunto da sociedade, quanto mais se afirma a igualdade como característica central de um povo, mais a liberdade ganha o tônus de responsabilidade. É que os iguais dispõem de reais condições de reagir altivamente às injustiças, desafios e provocações do cotidiano, de modo a refrear os excessos ou abusos, partam de onde partirem, venham de quem vierem. Donde o "Jornal da ABI" (Associação Brasileira de Imprensa) comentar que até mesmo os escandalosos tabloides ingleses, premidos pela perda de leitores, não raras vezes mudam sua linha sensacionalista de orientação; "Porque do regime da plena liberdade surge a responsabilidade, e o cidadão passa a não comprar porcaria" (Jornal da ABI 326, fevereiro de 2008, p. 25, a propósito de entrevista com o citado operador jurídico, jornalista e deputado Miro Teixeira).

30. Este o ponto nuclear da questão, à face de uma lógica especificamente referida à interação da imprensa livre com um público-alvo cada vez mais em condições de se posicionar à moda de filtro ou peneira do que lhe chega como informação ou como conhecimento pronto e acabado. Lógica encampada pela nossa Constituição de 1988, e prescientemente captada pelo inglês William Pitt (1759-1806), para quem "à imprensa deve tocar o encargo de se corrigir a si própria"; pelo norte-americano Thomas Jefferson (1743-1826), autor da afirmação de que, se lhe fosse dado escolher entre um governo sem jornais 
e jornais sem um governo, não hesitaria em optar por esta última fórmula, e pelo francês Alexis de Tocqueville (1805-1859), ao sentenciar que, numa democracia, o modo mais eficaz de se combater os excessos de liberdade é com mais liberdade ainda. A imprensa, então, cabalmente imunizada contra o veneno da censura prévia, como lúcida e corajosamente pregou o poeta John Milton, em 1644, no seu famoso discurso "A Aeropagítica" (discurso lido perante a suprema corte do parlamento inglês, transformado em livro pela Editora Topbooks, edição de 1999). A imprensa livre a viabilizar, assim, o ideal daqueles que, à semelhança de Gluksman, veem a liberdade como um rio impetuoso cujo único anseio é não ter margens. Não ter margens fixas - penso que seria melhor dizer - , pois a autorregulação da imprensa nunca deixa de ser um permanente ajuste de limites em sintonia com o sentir-pensar de uma sociedade civil de que ela, imprensa, é simultaneamente porta-voz e caixa de ressonância. Não só porta-voz, não só caixa de ressonância, mas as duas coisas ao mesmo tempo.

31. Atente-se para as novelas da televisão brasileira e demais programações em canal aberto. Não há censura prévia quanto à exposição de capítulos, cenas, fatos, mas os temas polêmicos ou de mais forte quebra de paradigmas culturais são retratados com perceptível cuidado. Cuidado ou acautelamento que nada tem a ver com o receio de intervenção estatal (proibida pela Constituição, ressalvado o estado de sítio), porém como o fruto mesmo de uma responsabilidade de imprensa cujo tamanho é medido com a trena da susceptibilidade dos telespectadores em geral, dos anteparos de cada família em particular para com os seus membros ainda em formação ou desenvolvimento, e dos próprios sistemas de ombudsman de que nenhum órgão de comunicação social pode abrir mão, hoje em dia. Até mesmo episódios verdadeiros, mas incomumente chocantes, o novo e irreversível modelo de imprensa evita expor para não traumatizar o público, sob o grande risco de perda de audiência. Exemplo disso foi o suicídio de um importante político estadunidense, inteiramente filmado pela televisão, mas levado ao ar sem a brutalidade do momento em que o suicida colocava o revólver no interior de sua própria boca para em seguida puxar o gatilho (fato de que tive ciência pelo relato oral do respeitável juiz federal da 5a região, Ricardo César Mandarino Barreto, presentemente oficiando como juiz auxiliar em meu próprio gabinete de ministro deste STF). Já os fatos e cenas de maior apelo sexual (os programas de reality show no meio), estes são exibidos em horário noturno mais avançado e com legenda quanto à sua natureza e não recomendação para determinadas faixas etárias. De conformidade, aliás, com o disposto no $§ 3$ o do art. 220 da Constituição. 
32. Verbalizadas tais reflexões e fincadas estas primeiras interpretações da Magna Carta Federal, também facilmente se percebe que a progressiva inafastabilidade desse dever da imprensa para com a informação em plenitude e sob o timbre da máxima fidelidade à sua base empírica é que passa a compor o valor social da visibilidade. Nova categoria de direito individual e coletivo ao real conhecimento dos fatos e suas circunstâncias, protagonismos e respectivas motivações, além das ideias, vida pregressa e propostas de trabalho de quem se arvore a condição de ator social de proa, principalmente se na condição de agente público. Visibilidade que evoca em nossas mentes a mensagem cristã do "conheceis a verdade e ela vos libertará" (João, 8:32), pois o fato é que nada se compara à imprensa como cristalina fonte das informações multitudinárias que mais habilitam os seres humanos a fazer avaliações e escolhas no seu concreto dia a dia. Juízos de valor que sobremodo passam por avaliações e escolhas em período de eleições gerais, sabido que é pela via do voto popular que o eleitor mais exercita a sua soberania para a produção legítima dos quadros de representantes do povo no Poder Legislativo e nas chefias do Poder Executivo. Mais ainda, visibilidade que, tendo por núcleo o proceder da Administração Pública, toma a designação de "publicidade" (art. 37, caput, da CF). Publicidade como transparência, anote-se, de logo alçada à dimensão de "princípio", ao lado da "legalidade", "impessoalidade", "moralidade" e "eficiência". Sendo certo que a publicidade que se eleva à dimensão de verdadeira transparência é o mais aplainado caminho para a fiel aplicação da lei e dos outros três princípios da moralidade, da eficiência e da impessoalidade na Administração Pública.

33. Daqui já se vai desprendendo a intelecção do quanto a imprensa livre contribui para a concretização dos mais excelsos princípios constitucionais. A começar pelos mencionados princípios da "soberania" (inciso I do art. 1ํ) e da "cidadania" (inciso II do mesmo art. 1ํㅡ), entendida a soberania como exclusiva qualidade do eleitor-soberano, e a cidadania como apanágio do cidadão, claro, mas do cidadão no velho e sempre atual sentido grego: aquele habitante da cidade que se interessa por tudo que é de todos; isto é, cidadania como o direito de conhecer e acompanhar de perto as coisas do Poder, os assuntos da pólis. Organicamente. Militantemente. Saltando aos olhos que tais direitos serão tanto melhor exercidos quanto mais denso e atualizado for o acervo de informações que se possa obter por conduto da imprensa (contribuição que a INTERNET em muito robustece, faça-se o registro).

34. Esse direito que é próprio da cidadania - o de conhecer e acompanhar de perto as coisas do Poder, e que a imprensa livre tanto favorece - nós 
mesmos do Supremo Tribunal Federal temos todas as condições para dizer a sua magnitude imprescindibilidade. É que a própria história deste nosso Tribunal já se pode contar em dois períodos: antes e depois da "TV JUSTIÇA", implantada esta pelo então presidente Marco Aurélio. TV JUSTIÇA a que vieram se somar a TV digital e a "RÁDIO JUSTIÇA" (criações da ministra Ellen Gracie, à época presidente da Corte), para dar conta das nossas sessões plenárias em tempo real. O que tem possibilitado à população inteira, e não somente aos operadores do Direito, exercer sobre todos nós um heterodoxo e eficaz controle externo, pois não se pode privar o público em geral, e os lidadores jurídicos em particular, da possibilidade de saber quando trabalham, quanto trabalham e como trabalham os membros do Poder Judiciário. Afinal, todo servidor público é um servidor do público, e os ministros do Supremo Tribunal Federal não fogem a essa configuração republicana verdadeiramente primaz.

35. Também deste ponto de inflexão já vai tomando corpo a proposição jurídica de que, pelo seu reconhecido condão de vitalizar por muitos modos a Constituição, tirando-a mais vezes do papel, a Imprensa passa a manter com a democracia a mais entranhada relação de mútua dependência ou retroalimentação. Falo da democracia como categoria jurídico-positiva (não simplesmente filosófico-política), que em toda Constituição promulgada por uma Assembleia Constituinte livremente eleita consubstancia o movimento, o fluxo ascendente do poder de governar a pólis; quer dizer, o poder de governar toda a coletividade como aquele que vem de baixo para cima, e não de cima para baixo da escala social. A implicar, por evidente, prestígio das bases governadas e limitação das cúpulas governantes. Um tirar o povo da plateia para colocá-lo no palco das decisões que lhe digam respeito. Donde figurar, ela, democracia, como questão ou causa verdadeiramente planetária, ao lado da ecologia e da ética na vida pública. Democracia que Abrahan Lincoln inexcedivelmente definiu como o governo do povo, pelo povo e para o povo, e que a epopeia constituinte de 1987-1988 assumiu como o princípio dos princípios da Constituição de 1988. O seu valor-continente, por se traduzir no princípio que mais vezes se faz presente na ontologia dos demais valores constitucionais (soberania popular, cidadania, dignidade da pessoa humana, valores sociais do trabalho e da livre-iniciativa, pluralismo político, só para citar os listados pelos incisos de I a V do art. 1ํ da nossa Lei Maior). Valorteto da Constituição, em rigor de Ciência, porque acima da democracia não há outro valor coletivo senão já situado do lado de fora de toda positividade jurídica brasileira. Valor incomparável, então, que, se vivido autenticamente, 
concretiza aquela parte do discurso de posse do presidente Roosevelt, em plena depressão econômica: "nada há a temer, exceto o próprio medo".

36. Avanço na tessitura desse novo entrelace orgânico para afirmar que, assim visualizada como verdadeira irmã siamesa da democracia, a imprensa passa a desfrutar de uma liberdade de atuação ainda maior que a liberdade de pensamento e de expressão dos indivíduos em si mesmos considerados. Até porque essas duas categorias de liberdade individual também serão tanto mais intensamente usufruídas quanto veiculadas pela imprensa mesma (ganha-se costas largas ou visibilidade - é fato - , se as liberdades de pensamento e de expressão em geral são usufruídas como o próprio exercício da profissão ou do pendor jornalístico, ou quando vêm a lume por veículo de comunicação social). $\mathbf{O}$ que faz de todo o capítulo constitucional sobre a comunicação social um melhorado prolongamento dos preceitos fundamentais da liberdade de manifestação do pensamento e de expressão em sentido lato. Comunicando-se, então, a todo o segmento normativo prolongador a natureza jurídica do segmento prolongado; que é a natureza de "DIREITOS E GARANTIAS FUNDAMENTAIS", tal como se lê no título de $n^{0}$ II da nossa Constituição. E para a centrada tutela de tais direitos e garantias é que se presta a ação de descumprimento de preceito fundamental, cujo status de ação constitucional advém da regra que se lê no $\S 1^{\circ}$ do art. 101 da nossa Lei Maior, literis: "A arguição de descumprimento de preceito fundamental, decorrente desta Constituição, será apreciada pelo Supremo Tribunal Federal, na forma da lei". Em suma, a virginal fundamentalidade de um preceito constitucional é repassada, logicamente, para outro ou outros preceitos constitucionais que lhe sejam servientes, ainda que esses outros preceitos façam parte de um conjunto normativo diverso. Como se dá, ilustrativamente, com os dispositivos constitucionais que limitam o poder de tributar da união, dos Estados, do Distrito Federal e dos Municípios (arts. de nos 150 a 152, inseridos no capítulo atinente ao Sistema Tributário Nacional), sabido que tal limitação ao poder tributante das nossas unidades federadas opera em favor dos direitos fundamentais que assistem às pessoas privadas quanto às suas propriedades, rendas e atividades de subsistência material e produção econômica (títulos de nos $\mathrm{II}$ e VII, notadamente).

37. Com efeito, e a título de outorga de um direito individual que o ritmo de civilização do Brasil impôs como conatural à espécie humana (pois sem ele o indivíduo como que se fragmenta em sua incomparável dignidade e assim deixa de ser o ápice da escala animal para se reduzir a subespécie), a Constituição proclama que "é livre a manifestação do pensamento, sendo 
vedado o anonimato" (inciso IV do art. 5으. Assim também, e de novo como pauta de direitos mais fortemente entroncados com a dignidade da pessoa humana, a nossa Lei Maior estabelece nesse mesmo art. 5o que: a) "é livre a expressão da atividade intelectual, artística, científica e de comunicação, independentemente de censura ou licença" (inciso IX); b) "é livre o exercício de qualquer trabalho, ofício ou profissão, atendidas as qualificações profissionais que a lei estabelecer" (inciso XIII); c) "é assegurado a todos o acesso à informação e resguardado o sigilo da fonte, quando necessário ao exercício profissional" (inciso XIV); d) "conceder-se-á habeas data: a) para assegurar o conhecimento de informações relativas à pessoa do impetrante, constantes de registros ou bancos de dados de entidades governamentais ou de caráter público: b) para a retificação de dados, quando não prefira fazêlo por processo sigiloso, judicial ou administrativo" (inciso LXXII). Discurso libertário que vai reproduzir na cabeça do seu art. 220, agora em favor da imprensa, com pequenas alterações vocabulares e maior teor de radicalidade e largueza. Confira-se:

Art. 220. A manifestação do pensamento, a criação, a expressão e a informação, sob qualquer forma, processo ou veículo, não sofrerão qualquer restrição, observado o disposto nesta Constituição.

38. É precisamente isto: no último dispositivo transcrito a Constituição radicaliza e alarga o regime de plena liberdade de atuação da imprensa, porquanto fala: a) que os mencionados direitos de personalidade (liberdade de pensamento, criação, expressão e informação) estão a salvo de qualquer restrição em seu exercício, seja qual for o suporte físico ou tecnológico de sua veiculação; b) que tal exercício não se sujeita a outras disposições que não sejam as figurantes dela própria, Constituição. Requinte de proteção que bem espelha a proposição de que a imprensa é o espaço institucional que melhor se disponibiliza para o uso articulado do pensamento e do sentimento humanos como fatores de defesa e promoção do indivíduo, tanto quanto da organização do Estado e da sociedade. Plus protecional que ainda se explica pela anterior consideração de que é pelos mais altos e largos portais da imprensa que a democracia vê os seus mais excelsos conteúdos descerem dos colmas olímpicos da pura abstratividade para penetrar fundo na carne do real. Dando-se que a recíproca é verdadeira: quanto mais a democracia é servida pela imprensa, mais a imprensa é servida pela democracia. Como 
nos versos do poeta santista Vicente de Carvalho, uma diz para a outra, solene e agradecidamente, "Eu sou quem sou por serdes vós quem sois".

39. É de se perguntar, naturalmente: mas a que disposições constitucionais se refere o precitado art. 220 como de obrigatória observância no desfrute das liberdades de pensamento, criação, expressão e informação que, de alguma forma, se veiculem pela imprensa? Resposta: àquelas disposições do art. 5을 versantes sobre vedação do anonimato (parte final do inciso IV); direito de resposta (inciso $\mathrm{V}$ ); direito a indenização por dano material ou moral à intimidade, à vida privada, à honra e imagem das pessoas (inciso $X)$; livre exercício de qualquer trabalho, ofício ou profissão, atendidas as qualificações profissionais que a lei estabelecer (inciso XIII); direito ao resguardo do sigilo da fonte de informação, quando necessário ao exercício profissional (inciso XIV).

40. Não estamos a ajuizar senão isto: a cabeça do art. 220 da Constituição veda qualquer cerceio ou restrição à concreta manifestação do pensamento, bem assim todo cerceio ou restrição que tenha por objeto a criação, a expressão e a informação, pouco importando a forma, o processo, ou o veículo de comunicação social. Isto é certo. Impossível negá-lo. Mas o exercício de tais liberdades não implica uma fuga do dever de observar todos os incisos igualmente constitucionais que citamos no tópico anterior, relacionados com a liberdade mesma de imprensa (a começar pela proibição do anonimato e terminando com a proteção do sigilo da fonte de informação). Uma coisa a não excluir a outra, tal como se dá até mesmo quando o gozo dos direitos fundamentais à liberdade de pensamento e de expressão da atividade intelectual, artística, científica e de comunicação, além do acesso à informação, acontece à margem das atividades e dos órgãos de imprensa (visto que o desfrute de tais direitos é expressamente qualificado como "livre"). Mas é claro que os dois blocos de dispositivos constitucionais só podem incidir mediante calibração temporal ou cronológica: primeiro, assegura-se o gozo dos sobredireitos (falemos assim) de personalidade, que são a manifestação do pensamento, a criação, a informação etc., a que se acrescenta aquele de preservar o sigilo da fonte, quando necessário ao exercício da profissão do informante, mais a liberdade de trabalho, ofício, ou profissão. Somente depois é que se passa a cobrar do titular de tais sobressituações jurídicas ativas um eventual desrespeito a direitos constitucionais alheios, ainda que também densificadores da personalidade humana; ou seja, como exercer em plenitude o direito à manifestação do pensamento e de expressão em sentido geral (sobredireitos de personalidade, reitere-se a afirmativa), sem a possibilidade de 
contraditar, censurar, desagradar e até eventualmente chocar, vexar, denunciar terceiros? Pelo que o termo "observado", referido pela Constituição no caput e no $\S 11^{\circ}$ do art. 220, é de ser interpretado como proibição de se reduzir a coisa nenhuma dispositivos igualmente constitucionais, como os mencionados incisos IV, V, X, XIII e XIV do art. 50. Proibição de se fazer tabula rasa desses preceitos igualmente constitucionais, porém sem que o receio ou mesmo o temor do abuso seja impeditivo do pleno uso das liberdades de manifestação do pensamento e expressão em sentido lato.

41. Sem que o receio ou mesmo o temor do abuso seja impeditivo do pleno uso das duas categorias de liberdade, acabamos de falar, porque, para a Constituição, o que não se pode é, por antecipação, amesquinhar os quadrantes da personalidade humana quanto aos seguintes dados de sua própria compostura jurídica: liberdade de manifestação do pensamento e liberdade de expressão em sentido genérico (aqui embutidos a criação e o direito de informar, informar-se e ser informado, como expletivamente consignado pelo art. 37, 1, da Constituição portuguesa de 1976, "versão 1997"). Caso venha a ocorrer o deliberado intento de se transmitir apenas em aparência a informação para, de fato, ridicularizar o próximo, ou, ainda, se objetivamente faz-se real um excesso de linguagem tal que faz o seu autor resvalar para a zona proibida da calúnia, da difamação, ou da injúria, aí o corretivo se fará pela exigência do direito de resposta por parte do ofendido, assim como pela assunção de responsabilidade civil ou penal do ofensor. Esta, e não outra, a lógica primaz da interação em causa.

42. Lógica primaz ou elementar - retome-se a afirmação - porque reveladora da mais natural cronologia das coisas. Não há como garantir a livre manifestação do pensamento, tanto quanto o direito de expressão lato sensu (abrangendo, então, por efeito do caput do art. 220 da CF, a criação e a informação), senão em plenitude. Senão colocando em estado de momentânea paralisia a inviolabilidade de certas categorias de direitos subjetivos fundamentais, como, por exemplo, a intimidade, a vida privada, a imagem e a honra de terceiros. Tal inviolabilidade, aqui, ainda que referida a outros bens de personalidade (o entrechoque é entre direitos de personalidade), não pode significar mais que o direito de resposta, reparação pecuniária e persecução penal, quando cabíveis; não a traduzir um direito de precedência sobre a multicitada parelha de sobredireitos fundamentais: a manifestação do pensamento e a expressão em sentido geral. Sendo que, no plano civil, o direito à indenização será tanto mais expressivo quanto maior for o peso, o tamanho, o grau da ofensa pessoal. Donde a Constituição mesma falar de direito de 
resposta "proporcional ao agravo", sem distinguir entre o agravado agente público e o agravado agente privado. Proporcionalidade, essa, que há de se comunicar à reparação pecuniária, naturalmente. Mas sem que tal reparação financeira descambe jamais para a exacerbação, porquanto: primeiro, a excessividade indenizatória já é, em si mesma, poderoso fator de inibição da liberdade de imprensa; segundo, esse carregar nas cores da indenização pode levar até mesmo ao fechamento de pequenos e médios órgãos de comunicação social, o que é de todo impensável num regime de plenitude da liberdade de informação jornalística. Sem falar que, em se tratando de agente público, ainda que injustamente ofendido em sua honra e imagem, subjaz à indenização uma imperiosa cláusula de modicidade. Isto porque todo agente público está sob permanente vigília da cidadania (é direito do cidadão saber das coisas do Poder, ponto por ponto), exposto que fica, além do mais, aos saneadores efeitos da parábola da "mulher de César": não basta ser honesta; tem que parecer. E quando o agente estatal não prima por todas as aparências de legalidade e legitimidade no seu atuar oficial, atrai contra si mais fortes suspeitas de comportamento antijurídico. O que propicia maior número de interpelações e cobranças em público, revelando-se claramente inadmissível que semelhantes interpelações e cobranças, mesmo que judicialmente reconhecidas como ofensivas, ou desqualificadoras, venham a ter como sanção indenizatória uma quantia tal que leve ao empobrecimento do cidadão agressor e ao enriquecimento material do agente estatal agredido. Seja como for, quer o ofendido esteja na condição de agente privado, quer na condição de agente público, o que importa para o intérprete e aplicador do Direito é revelar a vontade objetiva da Constituição na matéria. E esse querer objetivo da Constituição reside no juízo de que a relação de proporcionalidade entre o dano moral ou material sofrido por alguém e a indenização que lhe cabe receber (quanto maior o dano, maior a indenização) opera é no próprio interior da relação entre a potencialidade da ofensa e a concreta situação do ofendido. Nada tendo a ver com essa equação a circunstância em si da veiculação do agravo por órgão de imprensa. Repito: nada tendo a ver com essa equação de Direito Civil a circunstância da veiculação da ofensa por órgão de imprensa, porque, senão, a liberdade de informação jornalística deixaria de ser um elemento de expansão e de robustez da liberdade de pensamento e de expressão lato sensu para se tornar um fator de contração e de esqualidez dessa liberdade. Até de nulificação, no limite.

43. Já no que diz respeito à esfera penal, o esquadro jurídico-positivo também não pode ser de maior severidade contra jornalistas. Vale dizer, a 
lei não pode distinguir entre pessoas comuns e jornalistas para desfavorecer penalmente estes últimos, senão caminhando a contrapasso de uma Constituição que se caracteriza, justamente, pelo desembaraço e até mesmo pela plenificação da liberdade de agir e de fazer dos atores de imprensa e dos órgãos de comunicação social. Logo, é repelente de qualquer ideia de tipificação criminosa em apartado a conduta de quem foi mais generosamente aquinhoado pela Constituição com a primazia das liberdades de manifestação do pensamento e de expressão em sentido genérico.

44. Cuida-se, tal primazia, marcadamente em matéria de imprensa, de uma ponderação ou sopesamento de valores que a própria Constituição antecipadamente faz e resolve por um modo temporalmente favorecedor do pensamento e da expressão; ou seja, antes de tudo, duas coisas: uma, o ato de pensar em público ou para além dos escaninhos simplesmente mentais da pessoa humana, sabido que "manifestação de pensamento" implica esse transpasse de uma esfera simplesmente abstrata ou interna ao indivíduo para outra empírica ou externa; a segunda, o ato de se expressar intelectualmente, artisticamente, cientificamente e comunicacionalmente, a se dar, por evidente, no mundo das realidades empíricas. Somente depois de qualquer dessas duas atuações em concreto é que se abre espaço à personalíssima reação dos eventuais prejudicados na sua intimidade, vida privada, honra e imagem.

45. Nova pergunta é de se fazer, também sob a marca da imperiosidade: como entronizar o indivíduo nesses bens de personalidade que são a manifestação do pensamento e a expressão em sentido geral, se a ele é negada a possibilidade de fazer de cada obra sua um retrato falado de si mesmo? Se cada autor, cada escritor, cada pensador e cada artista tem por quintessência do seu DNA imaterial a ironia, por hipótese, como impedir que seja igualmente irônica a sua produção intelectual, ou artística, ou comunicacional? E se ele for um incréu (Millôr Fernandes fala do direito fundamental à descrença), um agnóstico, um iconoclasta, um evolucionista, um questionador, um anarquista ("Anarquistas, Graças a Deus", é o mais conhecido dos livros de Zélia Gattai), um arauto do holismo, da utopia $e$ do surreal, como impedir que venha a contraditar, incomodar, desagradar ou até mesmo ofender, chocar, vexar, revoltar quem não o seja? Como proibir que o indivíduo seja ele mesmo em tudo que fizer, de sorte a que tudo que ele fizer seja ele mesmo? Encarnado e insculpido, como se dizia em português dos tempos idos? Impossível, a não ser pelo raso e frio holocausto da liberdade de imprensa em nosso País.

46. Nessa toada de intelecção constitucional da matéria, quem quer que seja pode dizer o que quer que seja, ao menos na linha de partida das 
coisas, pois a verdade, a beleza, a justiça e a bondade - só para citar os quatro valores por excelência da filosofia grega - podem depender dessa total apriorística liberdade de pensamento e de expressão para poder vir a lume. $\mathrm{O}$ possível conteúdo socialmente útil da obra a compensar eventuais excessos de estilo e da própria verve do autor. Não é de René Descartes a máxima de que não lhe impressionava o argumento de autoridade, mas, isto sim, a autoridade do argumento? Não é de Voltaire a sentença de que "não concordo com uma só das palavras que dizeis, mas defenderei até à morte o vosso direito de dizê-las"? Sobremais, é no desfrute da total liberdade de manifestação do pensamento e de expressão lato sensu que se pode fazer de qualquer dogma um problema. Um objeto de reflexão e de intuição, para ver até que ponto o conhecimento tido por assente consubstancia, ou não, um valor em si mesmo. Para se perquirir, como o fizeram Galileu Galilei e Giordano Bruno, se determinado experimento ou uma dada teoria não passam de condicionamentos mentais, ou sociais, que nada têm a ver com as leis da natureza ou com a evolução espiritual da humanidade.

47. Sustentar o contrário parece-me postura de quem vaza os próprios olhos para não ter que enxergar esses dois enfáticos e geminados comandos constitucionais: primeiro, o de que os sobredireitos de personalidade aqui seguidamente vocalizados se caracterizam pelo seu exercício "livre" (incisos IV e IX do art. 5o da Constituição); segundo, o de se tratar de superiores direitos que, se manifestados por órgão de imprensa ou como expressão de atividade jornalística, passam a receber sobretutela em destacado capítulo da nossa Lei Maior (Capítulo V do Título VIII), pois a dupla verdade jurídico-científica traduz-se em que a imprensa tem o condão de favorecer o uso desses tão encarecidos direitos de personalidade (sobredireitos, nunca é demais repetir) e ainda se põe como vizinha de porta da democracia, essa verdadeira célula mater de todas as grandes virtudes coletivas. Condôminos, então (imprensa livre e democracia), de um metafórico edifício que a nossa Lei Maior ergueu para possibilitar à nação brasileira caminhar mais decidida e facilitadamente na direção de si mesma. Que possivelmente seja a direção de uma liberdade, de uma igualdade e de uma fraternidade mais afeiçoadas ao nosso modo preponderantemente sentimental, intuitivo, alegre, espontâneo, criativo e agregador de ser (a despeito das duas maiores nódoas ético-espirituais de toda a nossa formação enquanto colônia, reino unido e Estado soberano, que foram as imperecíveis nódoas da escravidão negra e do quase completo etnocídio das nossas populações indígenas). À guisa da exortação que se contém no "Conhece-te a ti mesmo", do oráculo de Delfos, e no "Torna-te quem és", do 
genial filósofo alemão Friedrich Nietzsche. Donde a precedente afirmação de que, à luz de uma Constituição que tanto favorece a liberdade de imprensa, não cabe sequer falar de um destacado sistema penal na matéria. Seria dar com uma das mãos e tomar com a outra, como vigorosamente advertia Geraldo Ataliba. Modo desinteligente de se interpretar dispositivos jurídicos (ao contrário, pois, do que preconizava Carlos Maximillano), mormente os encartados na Constituição.

48. Está-se primariamente a lidar, assim, com direitos constitucionais insuscetíveis de sofrer "qualquer restrição (...)", seja qual for a "forma, processo ou veículo" de sua exteriorização. O que vem a ser confirmado pelo $\S 1$ lo do mesmo artigo constitucional de no 220 , verbis:

Nenhuma lei conterá dispositivo que possa constituir embaraço à plena liberdade de informação jornalística em qualquer veículo de comunicação social, observado o disposto no art. 5, IV, V, X, XIII e XIV.

49. Tem-se agora um comando constitucional que vai mais longe ainda no seu decidido propósito de prestigiar a cronologia aqui defendida como de compulsória observância. Preceito constitucional que chega a interditar a própria opção estatal por dispositivo de lei que venha a "constituir embaraço à plena liberdade de informação jornalística em qualquer veículo de comunicação social". Logo, a uma atividade que já era "livre" foi acrescentado o qualificativo de "plena". Liberdade plena, entenda-se, no que diz respeito à essência mesma do jornalismo. Ao seu "núcleo duro", que são as coordenadas de tempo e de conteúdo da manifestação do pensamento e da criação lato sensu, quando veiculada por órgão de comunicação social. É o que se pode chamar de matéria centralmente de imprensa; ontológica ou axialmente de imprensa, devido a que os temas periféricos, estes, sim, a Constituição coloca ao dispor daquele poder estatal de legislar. Aqui, por se tratar de temas circundantes ou que giram na órbita da liberdade de informação jornalística (sem com essa liberdade se confundir, todavia), o poder estatal de legislar é de ser reconhecido. Ali, por se cuidar do núcleo ou da medula mesma da liberdade de informação jornalística, nenhum poder estatal de legislar é de subsistir.

50. Talvez com maior precisão hermenêutica: a liberdade de informação jornalística, para se revestir do pleno desembaraço que lhe assegura a Constituição, há de implicar interdição à lei quanto a duas nucleares dimensões: 
primeira, o tempo de início e de duração do seu exercício; segunda, sua extensão ou tamanho do seu conteúdo. Coordenadas de tempo e de conteúdo que exprimem o que vimos chamando de "núcleo duro" ou essência mesma da liberdade de imprensa. Seu epicentro. Restando claro que, se o Estado puder interferir nesse compactado núcleo, estará marcando limites ou erguendo diques para o fluir de uma liberdade que a nossa Lei Maior somente concebeu em termos absolutos: ou seja, sem a mínima possibilidade de apriorístico represamento ou contenção.

51. Essa interdição ao poder legislativo do Estado significa, então, que nem mesmo o Direito-lei tem a força de interferir na oportunidade/duração de exercício, tanto quanto no cerne material da liberdade de informação jornalística (conteúdo/extensão). Noutro dizer, liberdade que têm suas coordenadas temporais e materiais exclusivamente ao dispor do seu individualizado titular em cada caso concreto. Assumindo ele, óbvio, as consequências civis e penais que são próprias das pessoas ou agentes comuns. Além de não poder se opor a eventual direito de resposta. Direito que se manifesta como ação de replicar, ora para o efeito de simples retificação da matéria publicada, ora para o fim de centrado contradiscurso por parte daquele que se vê ofendido em sua subjetividade, ou, então, insultuosamente desqualificado enquanto pensador, cientista, criador, ou simples observador da cena existencial.

52. Um segundo desdobramento hermenêutico ainda se desprende dessa mesma interdição legislativa quanto à medula mesma da liberdade de informação jornalística: a de que, no tema, há uma necessária linha direta entre a Imprensa e a sociedade civil. Se se prefere, vigora em nosso ordenamento constitucional uma forma de interação imprensa/sociedade civil que não passa, não pode passar pela mediação do Estado. Interação que pré-exclui, portanto, a figura do Estado-ponte em matéria nuclear ou axialmente de imprensa. Tudo sob a ideia-força de que à imprensa incumbe controlar o Estado, e não o contrário, conforme ressalta o jornalista Roberto Civita, presidente da Editora Abril e editor da revista VEJA, com estas apropriadas palavras: "Contrariar os que estão no poder é a contrapartida quase inevitável do compromisso com a verdade da imprensa responsável" (p. 114 da edição especial de VEJA do dia 10 de setembro de 2008, ano 41, no 36).

53. Não cessa por aqui o mais firme compromisso da Constituição com esse fazer da imprensa o mais eficaz mecanismo de concreto gozo das liberdades de manifestação do pensamento e da expressão em seu sentido mais abrangente. É que o $§ 3^{\circ}$ do mesmíssimo artigo 220 ainda contém o seguinte 
relato: "É vedada toda e qualquer censura de natureza política, ideológica e artística". Com o que a nossa Magna Lei corrobora toda a gama dos sobredireitos fundamentais do indivíduo, no tema, porém no âmbito de um conjunto normativo ainda mais protegido contra as arremetidas antijurídicas do Estado e dos próprios agentes privados: o conjunto normativo que se veicula, justamente, pelo capítulo constitucional centralmente devotado à liberdade de imprensa, que é, justamente, o Capítulo V do Título VIII da Constituição (conjunto de preceitos fundamentais por arrastamento ou vívida solidariedade de conteúdo e fim, já deixamos assentado, pois nem todo preceito constante de uma Lei Fundamental é por ela mesma qualificado como "fundamental" perante outros do seu unitário lastro formal ou tessitura discursiva).

54. É hora de uma primeira conclusão deste voto e ela reside na proposição de que a Constituição brasileira se posiciona diante de bens jurídicos de personalidade para, de imediato, cravar uma primazia ou precedência: a das liberdades de pensamento e de expressão lato sensu (que ainda abarca todas as modalidades de criação e de acesso à informação, esta última em sua tríplice compostura, conforme reiteradamente explicitado). Liberdades que não podem arredar pé ou sofrer antecipado controle nem mesmo por força do Direito-lei, compreensivo este das próprias emendas à Constituição, frise-se. Mais ainda, liberdades reforçadamente protegidas se exercitadas como atividade profissional ou habitualmente jornalística e como atuação de qualquer dos órgãos de comunicação social ou de Imprensa. Isto de modo conciliado:

I - contemporaneamente, com a proibição do anonimato, o sigilo da fonte e o livre exercício de qualquer trabalho, ofício, ou profissão;

II - a posteriori, com o direito de resposta e a reparação pecuniária por eventuais danos à honra e à imagem de terceiros. Sem prejuízo do uso de ação penal também ocasionalmente cabível, nunca, porém, em situação de rigor mais forte do que o prevalecente para os indivíduos em geral.

55. Outra não podia ser a escolha da nossa Lei Maior, em termos operacionais, pois sem essa absoluta primazia do que temos chamado de sobredireitos fundamentais sobejariam falsas desculpas, sofismas, alegações meramente retóricas para, a todo instante, crucificá-los no madeiro da mais virulenta reação por parte dos espíritos renitentemente autoritários, antiéticos, ou obscurantistas, quando não concomitantemente autoritários, antiéticos e obscurantistas. Inimigos figadais, por consequência, da democracia e da imprensa livre. Do que aflora a nítida compreensão de que os bens jurídicos em confronto são daqueles que, em parte, se caracterizam por uma recíproca 
excludência no tempo. A opção que se apresentou ao Poder Constituinte de 1987-1988 foi do tipo radical, no sentido de que não era possível, no tema, servir ao mesmo tempo a dois senhores. Donde a precedência que se conferiu ao pensamento e à expressão, resolvendo-se tudo o mais em direito de resposta, ações de indenização e desencadeamento da chamada persecutio criminis, quando for o caso.

56. Dois parênteses, no entanto, devo abrir:

I - o primeiro, para dizer que estou a falar de direitos de personalidade, não na perspectiva da personalidade como instantâneo atributo de todo ser humano nativivo, assim regrado pelo art. $2^{\circ}$ do nosso Código Civil: "A personalidade civil da pessoa começa do nascimento com vida, mas a lei põe a salvo, desde a concepção, os direitos do nascituro". Artigo que faz da vida humana pósparto um automático centro subjetivado de direitos e obrigações, estas últimas pari passu ou em sintonia com o efetivo estádio mental de cada pessoa natural. Não é isso. Estou a falar de direitos de personalidade como situações jurídicas ativas que o Direito Constitucional vai positivando como expressão de vida humana digna. Direitos subjetivos que são ditados em harmonia com o grau de avanço cultural de cada povo, correspondendo à âncora político-filosófica de que não basta ao ser humano viver; é preciso fazê-lo com dignidade. Não como requisito de formação da personalidade, mas de sua justa e por isso mesmo imperiosa valorização. Logo, direitos subjetivos que densificam, entre nós, o princípio estampado no inciso III do art. $1^{\circ}$ da nossa Constituição, não por acaso nominado como "dignidade da pessoa humana". Mais ainda, direitos subjetivos que, antes de falar bem de toda e qualquer pessoa natural que os titularize, falam bem é da própria coletividade que os reconhece. Isto na medida em que tal coletividade se assume como capaz de conciliar, no bojo de sua própria Constituição, a mais avançada democracia com o mais atualizado humanismo. Enfim, direitos subjetivos que, ainda assim positivados como dignificação da personalidade humana a partir de um certo grau de evolução político-cultural desse ou daquele povo soberano, admitem temperamentos quando do seu entrechoque eficácio-temporal com outros direitos da mesma índole;

II - o segundo parêntese é para nos possibilitar dizer que essa hierarquia axiológica, essa primazia político-filosófica das liberdades de pensamento e de expressão lato sensu afasta sua categorização conceitual como "normasprincípio" (categorização tão bem exposta pelo jurista alemão Robert Alexy e pelo norte-americano Ronald Dworkin). É que nenhuma dessas liberdades se nos apresenta como "mandado de otimização", pois não se cuida de realizálas "na maior medida possível diante das possibilidades fáticas e jurídicas 
existentes" (apud Virgílio Afonso da Silva, em "A CONSTITUCIONALIZAÇÃO DO DIREITO - Os direitos fundamentais nas relações entre particulares", Malheiros Editores, p. 32-35, 2a tiragem). Tais possibilidades não contam, simplesmente, porque a precedência constitucional é daquelas que se impõe em toda e qualquer situação concreta. Assim na esfera de atuação do Estado quanto dos indivíduos. Logo, valendo terminantemente para todas as situações da vida em concreto, pouco importando a natureza pública ou privada da relação entre partes, ambas as franquias constitucionais encarnam uma tipologia normativa bem mais próxima do conceito de "normasregra"; isto em consideração ao fato de que, temporalmente, e com o timbre da invariabilidade, preferem à aplicação de outras regras constitucionais sobre direitos de personalidade. Não para invalidar estes últimos, mas para sonegar-lhes a nota da imediata produção dos efeitos a que se preordenam, sempre que confrontados com as liberdades de manifestação do pensamento e de expressão lato sensu. Mormente se tais liberdades se dão na esfera de atuação dos jornalistas e dos órgãos de comunicação social.

57. Parênteses fechados, retomo o fio do raciocínio hermenêutico-aplicativo para acrescentar que toda a lógica dos comandos constitucionais brasileiros, na matéria, ainda absorve uma outra interdição da faina legislativa do Estado. Refiro-me à impossibilidade de produção de uma "lei de imprensa", como tal entendido um diploma legislativo de feição orgânica ou estatutária. Diploma de máxima concentração material, porquanto exauriente dos temas essencialmente de imprensa, além daqueles de natureza periférica ou circundante.

58. Fácil demonstrar o acerto deste novo juízo. Primeiramente, sinta-se que as comentadas referências Constitucionais à lei (e, por implicitude, à função executiva do Estado) são para interditá-la quanto àquilo que verdadeiramente interessa: dispor sobre as coordenadas de tempo e de conteúdo das liberdades de pensamento e de expressão em seu mais abrangente sentido ("liberdade de informação jornalística" ou matéria essencialmente de imprensa, vimos dizendo). É afirmar: para a nossa Constituição, o concreto uso de tais liberdades implica um quando, um quê e um para quê antecipadamente excluídos da mediação do Estado, a partir da própria função legislativa. Confira-se, ainda uma vez, a própria voz da nossa Magna Carta Federal:

I - Art. 220. A manifestação do pensamento, a criação, a expressão e a informação, sob qualquer forma, processo ou veículo não sofrerão qualquer restrição, observado o disposto nesta Constituição (ou seja, 
observado apenas o que se contiver na própria Constituição. Não o que for acrescentado por modo legislativo, ou executivo);

$\S 1^{\circ}$ Nenhuma lei conterá dispositivo que possa constituir embaraço à plena liberdade de informação jornalística em qualquer veículo de comunicação social, observado o disposto no art. 5, IV, V, X, XIII e XIV; (de novo, observado tão somente o disposto nos dispositivos constitucionais de logo citados);

$\S 2$ e É vedada toda e qualquer censura de natureza política, ideológica e artística (disposição também proibitiva de atuação mediadora do Estado, e que, em verdade, incorre numa redundância somente explicável pelo deliberado intento da Constituição em se fazer expletiva, minudente, casuística, para que nenhuma dúvida interpretativa restasse quanto à pré-exclusão estatal nos encarecidos "quando", "como" e "quê" da liberdade de imprensa, com a única ressalva, vimos dizendo, do direito de resposta).

59. Ora, a razão de ser desse inequívoco bloqueio à mediação estatal, a partir da função legislativa (esse primeiro momento lógico da vida do Estado e do Direito), é justamente a entronização de sujeitos privados no gozo de franquias especificamente identificadas com toda concepção de imprensa livre. Franquias ou bens jurídicos ontologicamente de imprensa, porquanto constitutivos do que se poderia chamar, aristotelicamente, de causa formal dela própria. Visto que imprensa livre e desembaraço total no desfrute das liberdades aqui exalçadas são, para a nossa Constituição, uma coisa só. Uma realidade inapartável. Por isso que seu regime jurídico tem na Constituição mesma um concomitante ponto de partida e de chegada. Sem abertura de espaço para interposta legislação (quanto mais para a função executiva do Estado!), o que deixa sem sentido a edição de uma lei estatutária que já se sabe proibida de dispor sobre condutas - esse é o ponto - ontológica ou essencialmente de imprensa. Uma lei de imprensa que nada de axial ou elementarmente de imprensa pode conter.

60. Acresce que, ainda na esfera dos bens jurídicos ontologicamente fundidos com a noção de imprensa livre, o modo intransigente como a nossa Constituição impõe ao Estado o dever da não interferência acarreta para ele a lógica impossibilidade de dispor sobre o seu próprio modo de se omitir. Sobre o seu próprio jeito de suportar uma interdição que a Lei Fundamental impôs com todo rigor, pois esse tipo de interposta ação estatal terminaria por relativizar o que foi constitucionalmente concebido como absoluto. E 
concebido por modo absoluto como condição e garantia de sobre-eficácia do querer normativo da Constituição em tema tão cultural e politicamente sensível como a liberdade de imprensa.

61. De se ver que as normas constitucionais assim terminantemente proibitivas de atuação estatal intercalar se definem como de "eficácia plena e aplicabilidade imediata" (José Afonso da Silva, in "Aplicabilidade das Normas Constitucionais", Malheiros Editores, edição inicial de 1968), ou como normas constitucionais de pronta aplicação, conforme classificação que pessoalmente adotamos, na companhia do pranteado constitucionalista Celso Ribeiro Bastos ("Interpretação e Aplicabilidade das Normas Constitucionais", Editora Saraiva, 1982), porém, mais que isto, cuida-se de "normas irregulamentáveis". E normas irregulamentáveis porque, no caso, têm na própria interdição da interferência do Estado o seu modo cabal e ininterrupto de incidir. A sua natural condição de serena, total e permanente aplicabilidade. Acabado exemplo, primeiramente, de "normas íntegras, cheias, maciças, quando focadas sob o ângulo da matéria que veiculam, não apresentando frinchas ou brechas passíveis de colmatação, (...) pois nada se pode introduzir em algo que já é, por si, compacto" (p. 38 da sobredita obra conjunta). Depois disso, normas que incidem (as irregulamentáveis) "diretamente sobre os fatos regulados, repudiando qualquer regramento adjutório (...). É dizer, a vontade normativa surge e se exaure no próprio texto da Lei Suprema, como condição absoluta de respeito à sua manifestação originária" (p. 39 da mesma obra conjunta). O que robustece a anterior proposição do sem-sentido de uma lei eminentemente estatutária de imprensa em nosso País.

62. Não é tudo. Outro óbice lógico à confecção de uma lei de imprensa entre nós é que a serventia de uma lei orgânica ou estatutária não pode deixar de ser esta: aviar a segunda parte de um regime jurídico sobre determinado tema que a nossa Constituição intencionalmente iniciou para outro diploma normativo concluir. Tema ou figura de Direito que se inicia no corpo normativo da Magna Carta Federal, sim, mas apenas como intencional ou declarado ponto de partida. A própria Constituição a convocar o legislador de segundo escalão para o aporte regratório da parte restante, como, por amostragem, se dá com os seguintes dispositivos: a) art. 29, versante sobre a "lei orgânica" de cada Município brasileiro; b) art. 93, a respeito do "Estatuto da Magistratura"; c) $\S 5^{\circ}$ do art. 128, acerca do "estatuto de cada Ministério Público".

63. Decididamente, não é o caso da imprensa como figura de Direito Constitucional brasileiro. Em nenhum momento do seu falar imperativo a Constituição iniciou a regulação da matéria para outro diploma legislativo retomar e concluir, se a conduta é nuclearmente de imprensa. Bem ao 
contrário, em comportamentos da espécie o comando constitucional é intransponivelmente proibitivo da intromissão estatal, em qualquer das personalizadas esferas da Federação brasileira. Logicamente proibitivo, até, porque nenhuma lei pode ir além do que já foi a Magna Carta de 1988, simplesmente porque a nossa Constituição já foi ao máximo da proteção que se pode, teoricamente, conferir à liberdade da profissão de jornalista e de atuação dos meios de comunicação social. E se nenhuma lei pode ir além do que já foi constitucionalmente qualificado como "livre" e "pleno", a ideia mesma de uma lei de imprensa em nosso País soaria aos ouvidos de todo e qualquer operador do Direito como inescondível tentativa de embaraçar, restringir, dificultar, represar, inibir aquilo que a nossa Lei das Leis circundou com o mais luminoso halo da liberdade em plenitude.

64. É o quanto me basta para chegar a duas outras centradas conclusões deste voto: a) não há espaço constitucional para movimentação interferente do Estado em qualquer das matérias essencialmente de imprensa; b) a Lei Federal no 5.250/67, sobre disciplinar matérias essencialmente de imprensa, misturada ou englobadamente com matérias circundantes ou periféricas e até sancionatórias (de enfiada, portanto), o faz sob estruturação formal estatutária. Dois procederes absolutamente inconciliáveis com a superveniente Constituição de 1988, notadamente pelo seu art. 20 e $\S \S 1$ ํㅜ 2 e 6o dele próprio, a acarretar o kelseniano juízo da não recepção do Direito velho, todo ele, pela ordem constitucional nova. Circunstância que viabiliza o emprego da Arguição de Descumprimento de Preceito Fundamental como fórmula processual subsidiária da Ação Direta de Inconstitucionalidade - ADIN, nos termos das regras que se lê no $\S 1^{\mathrm{o}}$ do art. 102 da CF e no $\S 1^{\mathrm{o}}$ do art. $4^{\mathrm{o}}$ da Lei no 9.882/99 - Lei da ADPF. Fórmula instauradora de um substitutivo controle abstrato de constitucionalidade que se revela tanto mais necessário quanto envolto em concreta (agora sim) ambiência jurisdicional timbrada por decisões conflitantes. ${ }^{2}$

65. Sob esse prisma, não vale a contradita de ser a vigente Lei de Imprensa um diploma normativo contemporâneo da Carta de 1967, o que lhe propiciaria escapar, por dois aspectos, ao exame de compatibilidade com a ordem

2 Diz a lei da ADPF, pelo seu art. 1․: “A arguição prevista no § l do art. 102 da Constituição Federal será proposta perante o Supremo Tribunal Federal, e terá por objeto evitar ou reparar lesão a preceito fundamental, resultante de ato do Poder Público". "Parágrafo único. Caberá também arguição de descumprimento de preceito fundamental: 1 quando for relevante o fundamento da controvérsia constitucional sobre lei ou ato normativo federal, estadual ou municipal, incluídos os anteriores à Constituição" (caso da Lei de Imprensa). 
constitucional que lhe sobreveio (a de 1988): a) primeiro aspecto, atinente ao órgão estatal de que a lei agora sindicada proveio; b) segundo aspecto, alusivo à forma estatutária como a Lei no $5.250 / 67$ dispôs sobre as coisas. E não vale a contradita porque subsiste uma incompatibilidade material que é tão em bloco quanto insuperável. Explico.

66. A atual Lei de Imprensa foi concebida e promulgada num prolongado período autoritário da nossa história de Estado soberano, conhecido como "anos de chumbo" ou "regime de exceção" (período que vai de 31 de março de 1964 a princípios do ano de 1985). Regime de exceção escancarada ou vistosamente inconciliável com os arejados cômodos da democracia afinal resgatada e orgulhosamente proclamada na Constituição de 1988. E tal impossibilidade de conciliação, sobre ser do tipo material ou de substância (vertical, destarte), contamina toda a Lei de Imprensa:

I - quanto ao seu ardiloso ou subliminar entrelace de comandos, a serviço da lógica matreira de que para cada regra geral afirmativa da liberdade é aberto um leque de exceções que praticamente tudo desfaz;

II - quanto ao seu spiritus rectus ou fio condutor do propósito último de ir além de um simples projeto de governo para alcançar a realização de um projeto de poder. Projeto de poder que, só para ficar no seu viés político-ideológico, imprimia forte contratura em todo o pensamento crítico e remetia às calendas gregas a devolução do governo ao poder civil.

67. Sem maior esforço mental, por conseguinte, conclui-se que a lei em causa faz da liberdade de imprensa uma obra de impostura, distanciada a anos-luz da radical tutela que salta de uma Constituição apropriadamente apelidada de cidadã pelo deputado federal Ulysses Guimarães (presidente da Assembleia Nacional Constituinte de 1987-1988). Por ilustração, se o art. 1o da Lei de Imprensa, cabeça, assenta que "É livre a manifestação do pensamento e a procura, o recebimento e a difusão de informações ou ideias, por qualquer meio, e sem dependência de censura, respondendo cada um, nos termos da lei, pelos abusos que cometer", passa a dizer já no $\S 1^{\circ}$ desse mesmo artigo que "Não será tolerada a propaganda (...) de processos de subversão da ordem política e social (...)", e na mesma toada de prepotência e camuflagem discursiva, acrescenta no parágrafo subsequente que "O disposto neste artigo não se aplica a espetáculos e diversões públicas, que ficarão sujeitos à censura, na forma da lei, nem na vigência do estado de sítio, quando o Governo poderá exercer a censura sobre os jornais ou periódicos e empresas de radiodifusão e agências noticiosas nas matérias atinentes aos motivos que o determinaram, como também em relação aos executores daquela medida" (sem ao menos 
dizer "nos termos" ou "na forma da lei"). Por igual, se, no caput do seu art. $2^{\circ}$, estabelece que "É livre a publicação e circulação, no território nacional, de livros e jornais e outros periódicos $(. . .)^{\prime \prime}$, aí mesmo já principia a fragilizar o seu enunciado com um tipo de exceção que põe tudo abaixo: "salvo clandestinos ou quando atentem contra a moral e os bons costumes". Sobremais, impõe aos jornais e periódicos um regime tal de obrigações de registro e controle estatais que passa a corresponder ao mais rigoroso enquadramento com a ideologia de Estado então vigente (arts. 8o a 11). Já pelo seu art. 61, sujeita a apreensão os impressos que "contiverem propaganda de guerra ou de preconceitos de raça ou de classe, bem como os que promoverem incitamento à subversão da ordem política e social" (inciso I), ou, então, "ofenderem a moral pública e os bons costumes" (inciso 11). Apreensão que, de início é regrada como da competência do Poder Judiciário, a pedido do Ministério Público ( $§ 1^{\mathrm{o}}$ do mesmo art. 61), porém já na cabeça do art. de no 63 é transferida para o ministro da Justiça e Negócios Interiores, nas situações de urgência. E assim de ressalva em ressalva, de exceção em exceção, de aparentes avanços e efetivos recuos, a Lei no 5.250167 é um todo pro-indiviso que encerra modelo autoritário de imprensa em nada ajustado ao art. 220 da CF, mais os $\S \S 1$, $2^{\circ}$ e $6^{\circ}$ desse mesmo artigo, consagradores do clima de democracia plena que a nação passou a respirar com a promulgação da Magna Carta de 1988. Pior ainda, a Lei Federal no 5.250/67 é tão servil do mencionado "regime de exceção", tão objetivamente impregnada por ele, que chega a ser um dos seus principais veículos formais de concreção. O próprio retrato falado é símbolo mais representativo, no plano infraconstitucional, de toda aquela desditosa quadra de amesquinhamento dos foros de civilidade jurídica do Brasil.

68. Tudo isto sem falar nos capítulos em que ela, Lei de Imprensa, define crimes e comina penas por "ABUSOS NO EXERCÍCIO DA LIBERDADE DE MANIFESTAÇÃO DO PENSAMENTO E INFORMAÇÃO" (Capítulo de $n^{-}$III, que vai dos arts. 12 a 28), seguido daquele que versa o tema da "RESPONSABILIDADE PENAL" (Capítulo de $\mathrm{n}^{\circ} \mathrm{V}$, compreendendo os arts. de $n^{\circ}$ os 37 a 48). Quando é da lógica perpassante dos mesmíssimos preceitos constitucionais (art. 220 e seus $\S \S 1^{\circ}, 2^{\circ}$ e $6^{\circ}$ ) o comando de que os eventuais abusos sejam detectados caso a caso, jurisdicionalmente (é abusivo legislar sobre abusos de imprensa, averbo), pois esse modo casuístico de aplicar a Lei Maior é a maneira mais eficaz de proteção dos superiores bens jurídicos da liberdade de manifestação do pensamento e da liberdade de expressão lato sensu. E já vimos que o tratamento penal mais gravoso para condutas de imprensa implica discriminar quem, precisamente, retira do linguajar 
prescritivo da nossa Constituição apoio incondicionado para o seu agir e o seu fazer na matéria.

69. Ora bem, presente esse vasto panorama, o intérprete jurídico não tem como deixar de se render às seguintes coordenadas: quando a colisão entre a lei menor e a Constituição Federal se dá em quase toda essa cadeia de técnica redacional, fio condutor das ideias e finalidades político-ideológicas a alcançar, o que toma corpo não é simplesmente uma antinomia material entre dispositivos de desigual hierarquia. $\mathbf{O}$ que em verdade se tem é uma realidade marcada por diplomas normativos ferozmente antagônicos em sua integralidade. Visceralmente contrários, em suas linhas e entrelinhas. Por isso que imprestável, o de menor escalão hierárquico, para tentativas de conciliação hermenêutica com o de maior envergadura hierárquica, seja mediante expurgo puro e simples de destacados dispositivos da lei, seja mediante o emprego dessa refinada técnica de controle de constitucionalidade que atende pelo nome de "interpretação conforme a Constituição". É que até mesmo a técnica de interpretação conforme tem limites. Ela significa, sim, a recusa de incidência a um determinado sentido desse ou daquele preceito da lei interpretada, por incompatibilidade com a Constituição Federal, mas sob a condição de que semelhante operação não acarrete indeterminabilidade de sentido da parte remanescente da lei em causa. É dizer, a técnica da interpretação conforme não pode artificializar ou forçar a descontaminação da parte restante do diploma legal interpretado, pena de descabido incursionamento do intérprete em legiferação por conta própria. Reescrevendo ele, em verdade, o texto interpretado (o que não se admite jamais), pois o fato é que tal artificialização ou reescritura importa o desmonte da própria razão de ser de todo o conjunto da obra legislativa de menor galardão. Assim como quem transforma, num passe de mágica, o mais poluído pântano em cristalina água da fonte. Espécie de emenda insuscetível de salvar um soneto que tem em cada um dos seus versos a motivação e o significado, não apenas do verso anterior ou dos versos anteriores, não somente do verso posterior ou dos versos posteriores, mas de todos eles em congruente e inapartável unidade. Caso-limite ou situação extrema de interpretação necessariamente, conglobante ou por arrastamento teleológico, a pré-excluir do intérprete/aplicador do Direito: primeiro, qualquer possibilidade da declaração de inconstitucionalidade de destacados dispositivos da lei sindicada, mas permanecendo incólume uma parte sobejante que já não tem significado autônomo; segundo, a possibilidade da declaração tão somente de não incidência de um ou de mais de um significado desse ou daquele 
isolado preceito da lei de menor hierarquia frente à Constituição. Formulação teorética, esta (que ora vocalizo), imperiosamente ditada pela consideração de que, no particular, deixam de ter prestimosidade dois métodos de interpretação jurídica: a) o método teleológico, sabido que não se muda, a golpes de interpretação, o telos ou a finalidade da norma interpretada; b) o método sistemático, dada a impossibilidade de se preservar, após artificiosa hermenêutica de depuração, a coerência ou o equilíbrio interno de uma lei (a Lei Federal no 5.250/67) que foi ideologicamente concebida e maquinadamente escrita para operar em bloco. Urdida e concretamente redigida sob os auspícios do pensar maquiavélico de que o bem deve ser feito aos poucos, enquanto o mal, de uma vez só. No caso, o mal do estrangulamento da liberdade de imprensa a ser perpetrado pelas tenazes de um só conjunto monolítico de regras legais, acumpliciadamente dispostas numa completa unidade de desígnios quanto ao seu conteúdo e finalidades próximas e remotas.

70. Convergentemente, é a linha de ponderação de Jorge Miranda assim me parece - , quando lembra que, "se convém proceder, com a maior eficácia possível, à expurgação do sistema jurídico de normas contrárias à Constituição, ela torna-se ainda mais necessária para normas anteriores do que para normas posteriores, visto que estas são decretadas por órgãos por ela criados e que se presume segundo seus critérios e valores, ao passo que as normas de Direito anterior são resquícios de um sistema ou de uma ideia de Direito que a Constituição erradicou definitivamente" (em Manual de Direito Constitucional, II, 2a edição revista, p. 350, Coimbra Editora, 1982). Também assim J. J. Gomes Canotilho, para quem a inconstitucionalidade parcial implica o reconhecimento da invalidade total de um enunciado normativo "quando, em consequência da declaração de inconstitucionalidade de uma norma, se reconheça que as normas restantes, conforme à Constituição, deixam de ter qualquer significado autônomo (critério da dependência). Além disso, haverá nulidade total quando o preceito inconstitucional fazia parte de uma regulamentação global, à qual emprestava sentido e justificação (critério da interdependência)" (in Direito Constitucional, 64. edição revista e ampliada, p. 1.078, editora Almedina, 1993). É o que J. P. Lebreton designa por "solidariedade política" entre as diferentes normas da lei, a se traduzir num enlace operacional de permanente inseparabilidade (in "Les particularités de la juridiction constitucionnelle", RDP, 1983, no 2, p. 437-438, apud Rui Medeiros, em "A decisão de inconstitucionalidade: os autores, o conteúdo e os feitos da decisão de inconstitucionalidade da lei", Lisboa, Universidade Católica Editora, 1999, p. 424). 
71. Em conclusão, voto, inicialmente, pela confirmação do recebimento da presente ADPF. Quanto ao mérito, encaminho o meu voto no sentido de sua total procedência (dela, $\mathrm{ADPF}$ ), para o efeito de declarar como não recepcionado pela Constituição de 1988 todo o conjunto de dispositivos da Lei Federal no 5.250, de 9 de fevereiro de 1967, nele embutido o de natureza penal (compreensivo dos preceitos definidores de crimes, impositivos de penas e determinantes de responsabilidades).

É como voto. 